\title{
ANALISIS STRATEGI PERENCANAAN PESAN PADA AKUN INSTAGRAM E-COMMERCE @thekufed
}

\section{THE MESSANGE'S PLANNING STRATEGY OF INSTAGRAM ACCOUNT @ thekufed}

\author{
Dhita Widya Putri, Maulida De Mormes \\ (dhita.wp@1spr.edu, audi.momes13@gmail.com) \\ (Graduate School of Communication, London School of Public Relations, Jakarta)
}

\begin{abstract}
Abstrak
Instagram merupakan media sosial yang memiliki kekuatan visual. Dengan kekuatannya ini, banyak pihak baik individu maupun organisasi menggunakannya untuk menarik perhatian masyarakat dari informasi yang disampaikan. PT. Hood Digital Asia (Kufed) dengan akun Instagram nya, @ thekufed merupakan salah satu perusahaan e-commerce yang memiliki strategi sendiri dalam perencanaan pesan pada akun Instagram @ thekufed. Penelitian ini ingin mengungkapkan bagaimana strategi perencanaan pesan pada akun Instagram @ thekufed. Metode yang digunakan oleh peneliti dalam penelitian ini adalah metode kualitatif deskriptif. Dalam pembahasan penelitian ini menghasilkan beberapa strategi yang digunakan oleh Kufed dalam perencanaan konten pesan pada akun Instagramnya antara lain Instagram @ thekufed digunakan sebagai teaser, pendekatan melalui community building, bekerja sama dengan influencers untuk produksi konten dan kurasi produk, serta perancangan cerita untuk memperkuat konten visual dengan strategi emotionless. Kesimpulan dalam penelitian ini adalah strategi yang dirancang oleh tim Kufed sudah dilakukan dengan maksimal karena strategi tersebut didasari oleh konsep dan karakternya.
\end{abstract}

Kata Kunci: Strategi, Perencanaan Pesan, Instagram

\begin{abstract}
Instagram is a social media that has a visual power. Together with, many parties both individuals and organizations use Instagram to get some information they want to convey. For instance, PT. Hood Digital Asia (Kufed) who created @ thekufed account to develop their messages that will be delivered to their publics. They used their own strategy by adjusting the characters and the concepts with their targets. Therefore, this study explored about how @ thekufed designed their messages strategy. The researcher used qualitative method with descriptive approach to examine Kufed's message plan and strategy, such as teaser, community building, collaboration with influencers for content production and curation of products, as well as planning the story to strengthen the visual content with emotionless. The conclusion is Kufed has implemented the message strategy based on its concept and character.
\end{abstract}

Keywords: Strategy, Planning Messages, Instagram

\section{Pendahuluan}

Perubahan pola komunikasi yang saat ini terjadi pada masyarakat ditandai dengan munculnya internet. Dimana internet memungkinkan hampir semua orang di belahan dunia dapat saling terhubung dan berkomunikasi tanpa batas. Selain itu, internet mengubah cara berkomunikasi yang tadinya bermodel "satu-untuk-banyak" (model pada media konvensional misalnya seperti televisi) menjadi "banyak-untuk-satu” (dari jutaan

pengguna ke sebuah situs) bahkan "banyak-untuk-banyak" (forum online, milis, dan sebagainya) dengan cara komunikasi yang lebih terdesentralisasi dan lebih demokratis (Severin dan Tankard, 2011). Kontribusinya akan sistem komunikasi yang berjaringan ini bermanfaat untuk masyarakat, dengan hanya melalui sebuah komputer, internet hadir untuk publik yaitu sebagai media massa baru. 
Perkembangan internet terbilang fenomenal. Baik dari jumlah pengguna maupun jumlah komputer induknya (host computer). Host computer dapat mengukur besarnya perkembangan internet beberapa tahun silam karena, Host computer merupakan tempat penyimpanan informasi melalui jaringan. Jumlah pengguna Internet dunia pada Bulan Juni tahun 2016 ini terhitung sebesar 7.340.093.980, bahkan di Indonesia sendiri, Asosiasi Penyelenggara Jasa Internet Indonesia (APJII) mengungkapkan jumlah pengguna internet di Indonesia mencapai 88 juta orang hingga akhir tahun 2014 (APJII, 2015: 20). Salah satu faktor penunjang perkembangan internet yang begitu pesat adalah sifatnya yang cepat dan mudah. Dengan begitu, masyarakat dari berbagai belahan dunia dapat saling berkomunikasi satu sama lain tanpa batas dalam satu dunia baru bernama cyberspace.

\section{INTERNET USAGE STATISTICS \\ The Internet Big Picture \\ World Internet Users and 2016 Population Stats}

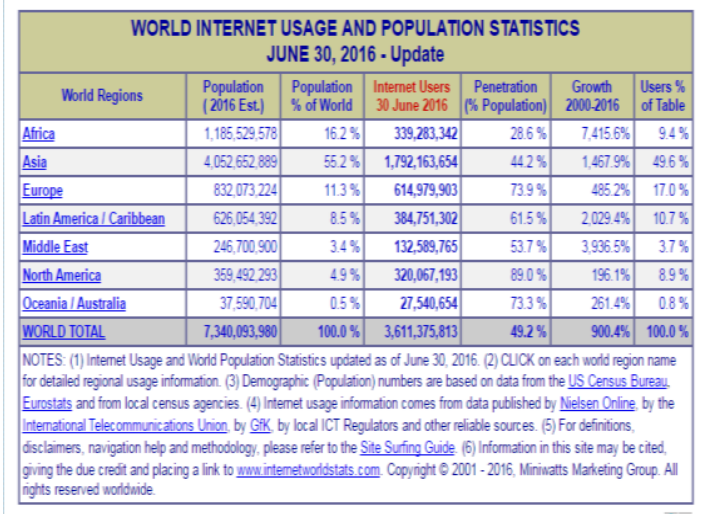

Gambar 1. Statistik Pengguna Internet

Dunia Per Juni 2016, sumber dari: Internet World Stats, 2016

Perkembangan internet melahirkan fenomena media sosial. Hal ini dipicu dengan kemunculan komunitas virtual pada tahun 90-an, dimana komunitas tersebut memanfaatkan fitur-fitur dari internet yaitu sosial media mulai dari chatting sampai berbagi status dengan pengguna lainnya seperti pada Friendster yang muncul pada tahun 2002 yang diikuti oleh beberapa media sosial lainnya seperti myspace.com pada tahun 2003, facebook pada tahun 2004, youtube pada tahun 2005, serta twitter pada tahun 2006 (Hayden dan Tomal, 2012). Banyak kelebihan yang masyarakat dapatkan saat menggunakan media sosial, salah satunya yaitu interaksi yang terjalin di dunia maya sebagai sarana pertukaran informasi, dengan satu klik saja seseorang sudah dapat berbincang dan berinteraksi dengan teman, saudara maupun rekan kerja di tempat yang jauh tanpa terhambat ruang dan waktu.

Dampak dari kekuatan media sosial tidak hanya dirasakan oleh individu saja, melainkan juga dirasakan bagi para pengusaha. Hal ini dapat dilihat bahwa hampir semua perusahaan di dunia terutama di Indonesia mempergunakan internet terutama media sosial seperti Facebook, Twitter, Youtube maupun Instagram sebagai media eksistensi perusahaan, sebagai media informasi, dan media komunikasi antara perusahaan dan juga publik mereka. Instagram banyak dipilih masyarakat mulai dari individu sampai sebuah organisasi untuk menjalankan bisnis maupun melakukan brand awareness dan menunjukkan eksistensi perusahaan karena daya tarik efek visual dari Instagram yang menjadi faktor sebuah perusahaan menjadikan Instagram sebagai salah satu platform media sosial untuk berinteraksi dan membagi informasi kepada followers-nya.

Fakta yang diperoleh dari Instagram pada Juni 2016, bahwa Instagram sudah mempunyai lebih dari 500 juta pengguna dimana 300 juta diantaranya menggunakan Instagram setiap harinya. 80 persen penggunanya sendiri berasal dari luar Amerika Serikat seperti Indonesia. Setiap harinya, ada 4,2 miliar tanda like dan lebih dari 95 juta foto atau video dibagikan ke sesama pengguna (Rachmatunnisa, 2016, Juni 22). Berdasarkan pernyataan di atas, peneliti memfokuskan penelitian ini terhadap perencanaan pesan sebuah akun media 
sosial Instagram PT Hood Digital Asia @ thekufed yang memiliki jumlah pengikut sebanyak 1.944 followers, 529 posts, dan 55 following per tanggal 28 Oktober 2016 pada pukul 16.16 WIB.

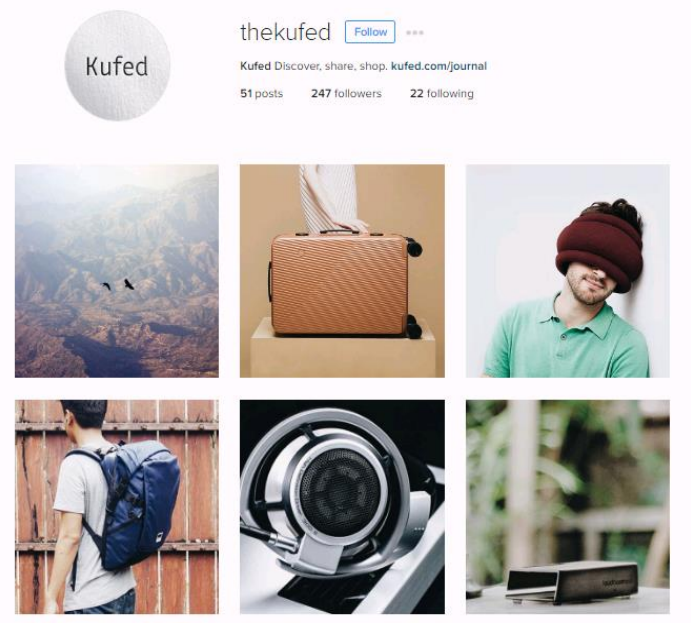

Gambar 2. Instagram page

@ thekufed dari Instagram.com, 2016

Menurut hasil pengamatan praresearch, interaksi yang didapatkan oleh akun Instagram @thekufed, dapat dilihat bahwa penyampaian informasi dilakukan dengan tulisan dan visual kepada para pengikutnya (followers). Pemilihan gambar, bahasa dan kata untuk caption setiap foto yang memiliki resolusi tinggi atau HD (high definition). Kufed juga merupakan perusahaan start up yang bergerak di bisnis online yang sedang melakukan brand awareness. Oleh karena itu, ada beberapa strategi dalam perencanaan pesan yang dilakukan oleh Kufed dalam akun media sosial Instagram mereka. Konsep dari Kufed adalah sebuah social-commerce yang berbasis aplikasi mobile dan website dimana Kufed menyediakan produk yang sudah dipilih (curated products) oleh para kurator dari Kufed dengan mempertimbangkan kualitas dan eksklusivitas dari produk tersebut. Tidak hanya itu, Kufed menyediakan tempat bagi para penggunanya untuk membeli, menemukan barang kesukaan mereka serta dapat membagi informasi dengan sesama pengguna lainnya yang berbentuk foto atau posting-an di akun pribadi pengguna mobile apps tersebut.
Dengan pemaparan ini, peneliti tertarik untuk mencari tahu dan menganalisis mengenai bagaimana strategi perencanaan pesan pada akun Instagram @ thekufed yang dimiliki oleh PT Hood Digital Asia (Kufed) sebagai perusahaan startup yang bergerak di bidang perniagaan melalui internet (e-commerce). Sehingga dirumuskanlah pertanyaan penelitian "Bagaimana Strategi Perencanaan Pesan Pada Akun Instagaram @thekufed?" yang bertujuan untuk mengetahui bagaimana strategi perencanaan pesan pada akun Instagram @ thekufed.

Teori dan konsep yang digunakan dalam penelitian ini adalah Teori Rencana dan logika pesan, serta Teori New Media. Pada Teori rencana dan logika pesan, dikatakan bahwa rencana adalah sebuah proses yang dilalui seseorang dalam merencanakan perilaku komunikasi untuk mencapai sebuah tujuan (Berger dalam Morissan, 2013). Dimana sebuah perencanaan itu merupakan bagian dari proses pemikiran berbagai rencana dan tindakan. Dalam sebuah perencanaan terdapat penyusunan logika pesan (O'Keefe dalam Littlejohn, 2008) yang terdiri dari; Logika ekspresif, yaitu komunikasi untuk pengungkapan pemikiran yang bersifat terbuka dan reaktif. Selanjutnya yaitu logika konvensional, dimana komunikasi berperan untuk menyusun pesan-pesan yang sopan, tepat, dan didasarkan pada aturan-aturan yang diketahui setiap orang. Terakhir adalah logika retoris, yaitu penyusunan pesan dengan luwes, berwawasan, dan terpusat.

Perencanaan pesan yang dimaksud dalam penelitian ini terdapat dalam ranah media baru. Dalam teori New Media, dijelaskan bahwa ada karakteristik khusus pada media baru (Lister, 2009: 13) antara lain:

1. Digital, dimaksudkan bagaimana bentuk data digital ini dapat menjadi lebih baik penggunaannya dari data analog 
dalam segi kecepatan dan segi kebenarannya.

2. Interaktivitas, menjadi karakteristik favorit, karena dapat menghemat waktu, secara langsung dapat kita kendalikan dalam komunikasi dua arah dapat terjadi hanya dengan media komputer saja.

3. Hypertextual, yang berarti sebuah teks yang dapat mengizinkan kita untuk mengakses teks-teks lain. Dengan adanya mengklik suatu teks saja yang sudah terdapat link didalamnya, maka para pengguna dapat terhubung dengan halaman lain dengan isi teks yang berbeda.

4. Dipersal, yaitu produksi, distribusi dan konsumsi tidak terpusat karena setiap pengguna internet dapat sesuka hati menjadi produsen, distributor atau hanya sekedar konsumen (personal freedom).

Virtuality, merupakan karakter untuk yang ada di dalam media baru. Ini adalah sebuah presepsi terhadap objekobjek immaterial, karena media baru juga memiliki unsur presence atau wujud dari kehadirannya bukan berupa fisik atau sering disebut dunia maya. Hal ini menjadi pemicu terbentuknya karakter budaya baru, yakni budaya virtual.

\section{Metodologi}

Penelitian ini menggunakan metode kualitatif, dengan tujuan untuk mengkonstruksi realitas dan memahami maknanya (Somantri, 2005). Metode kualitiatif merupakan metode yang memperhatikan proses, peristiwa, dan otentisitas yang mengedepankan pencarian data-data, yang dalam penelitian ini adalah berasal dari dokumen. Kualitatif deskriptif dipilih untuk dapat memperoleh data yang akurat dan secara mendalam mengenai topik penelitian.

Metode pengumpulan data berupa wawancara mendalam kepada 6 orang narasumber, yaitu; Admin dan Marketing Executive@ @thekufed, Konsultan @ thekufed, Tim Kreatif @ thekufed, Graphic Designer @ thekufed, Praktisi Media Sosial, dan Akademisi di bidang
Media Sosial.

\section{Hasil dan Pembahasan}

1. Bagian Logika Ekspresif

Kesuksesan membangun sebuah perusahaan online start up tidak terlepas dari bagaimana perusahaan tersebut mengoptimalisasikan penggunaan medianya. Salah satunya dengan perencanaan pesan dan pemilihan strategi yang tepat agar informasi yang ingin disampaikan dapat tercapai sesuai dengan tujuannya. Dalam logika ekspresif, terjadi proses komunikasi untuk pengungkapan pesan yang bersifat terbuka dan reaktif (O'Keefe dalam LittleJohn, 2009). Dalam kasus ini, Kufed memilih strategi untuk dapat memenuhi tujuannya yaitu branding dan awareness.

Strategi pertama adalah dengan menggunakan Instagram dan berbagai fiturnya sebagai media utama untuk menyebarkan informasi baik sebagai promosi maupun aktivitas yang sedang berlangsung dalam perusahaan tersebut, yang perencanaan pesannya dilakukan dengan memakai unsur visual berupa foto, video, dan gif dimana hal ini dapat mempermudah sekaligus menarik perhatian masyarakat dibanding hanya sekedar tulisan saja. Seperti yang dipaparkan oleh Konsultan Kufed bahwa,

"kita buat dari berbagai macam bentuk konten, baik berupa foto, gif, maupun video tergantung pada nature konten yang dibuat itu bagusnya seperti apa. [...] Kita akan siapkan konten sebanyak-banyaknya kaya yang buat di journal atau blog kita, kita kerjasama dengan influencer siapa, lalu kita angkat cerita unik dari mereka, baik dari sisi karir, personality maupun hal-hal yang bisa inspirasi banyak orang dari cerita tersebut. Tidak hanya dari influencer aja, kita juga kerjasama dengan brand-brand yang udah kerjasama dengan kita untuk bisa bikin konten bareng mereka, kayak misalkan kita bikin cerita dari pembuatan 
dari produk-produk mereka dan lain sebagainya."

Tergambar jelas bahwa Kufed menggunakan strategi dalam membuat konten yang dirancang khusus oleh tim kreatif dan tim desainnya, sekaligus berkolaborasi dengan influencers dan bloggers sebagai opinion leader dengan tujuan dapat lebih mendekatkan Kufed dengan masyarakat dan menyalurkan informasi secara efisien kepada pengikut yang dimiliki oleh masing-masing influencers. Selain itu, bekerjasama dengan influencer adalah ingin upaya untuk menjalankan community building, dimana Kufed ingin mendekatkan dan membangun hubungan dengan melibatkan targetnya kedalam sebuah aktivitas tertentu. Hal ini didukung oleh pernyataan dari Marketing Executive Kufed bahwa,

"Kita bekerjasama dengan influencers yang kita yakini mereka memang ahli dalam bidangnya masingmasing untuk membuat konten pada akun Instagram kami, seperti bekerjasama dengan Fashion Photographer dimana kita meminta mereka untuk foto barangbarang fashion yang memang kita adakan di Kufed ini namun tetap dengan style photo dan taste dia sendiri. Selain Photographer, kita juga kerjasama dengan illustrator, stylist, musician, seniman, dan masih banyak lagi, yang pasti kami yakin mereka merupakan orang-orang professional yang memang ahli di bidang masing-masing, bukan hanya sekedar tenar karena followers yang banyak di instagram-nya".

Terlihat bahwa Kufed cukup selektif dalam memilih strategi marketingnya. Seperti pemilihan influencers yang diajak untuk bekerjasama. Tidak hanya influencers yang memiliki followers banyak saja, namun lebih mengedepankan keahliannya di bidang yang ditekuni. Keterangan ini juga dipertegas oleh Graphic Designer Kufed bahwa,

"Kami memang memproduksi konten sendiri, baik dari segi visual maupun text- nya. [...] seperti video misalnya, kita juga kerjasama sama influencer [...] Kufed sendiri basically memang visual banget, terus strategi awal marketing dari Kufed itu kan emotionless, dimana kita ingin memperlihatkan ke masyarakat kalo Kufed itu dibuat sebagai wadah informasi juga. Dan menurut kita, emotionless sendiri membuat kesan exclusive juga".

Berdasarkan keterangan yang telah dipaparkan, dapat dikatakan bahwa Kufed merencanakan konten-kontennya dengan bekerjasama dengan influencer misalnya membuat video. Hasil dari kerjasama tersebut, akan diolah lagi agar menjadi sebuah konten yang baik dan sesuai dengan cipta dan selera Kufed. Hal ini menunjukkan Kufed mengedepankan orisinalitas dan kualitas kontenya. Bersama ini pula, Praktisi dan Akademisi media sosial mendukungpenrnyataan tersebut.

"[...] sekarang orang lebih tertarik kepada quality content sebuah post. Bukan hanya dari segi visual yang bagus saja, melainkan apa sih yang menarik dari post tersebut. Salah satu cara membuat hal itu menarik adalah membuat sebuah cerita yang sesuai dengan karakter audience yang mau kita tuju. Kalau target kita adalah orang-orang yang suka fashion, maka kita harus juga buat content yang menarik tentang fashion [...] Jadi, kita juga sharing informasi sesuai dengan desire mereka. Selain itu, sekarang strategi yang bisa dipertimbangkan untuk dilakukan adalah kolaborasi."

Berdasarkan pernyataan di atas disimpulkan bahwa melakukan kolaborasi, yaitu bekerjasama dengan influencer merupakan suatu strategi yang direkomendasikan, agar tujuan yang ingin dicapai akan lebih mudah dan manfaatnya akan lebih banyak. Dengan adanya kolaborasi ini, potensi keragaman konten yang dibuat semakin tinggi dan dapat membedakan Kufed dengan para pesaingnya. Tentunya pihak yang diajak untuk bekerjasama memiliki banyak 
pengikut (followers). Selain bekerjasama dengan influencers, Kufed memiliki strategi pesan atau text yang diungkapkan secara emotionless yang artinya keterangan yang ditulis tanpa mengungkapkan dan menggunakan emosi (datar). Dimana kesan "berjualan" atau hard selling tidak begitu tampak.

Dalam pemanfaatan media sosial Instagram, tidak semua fitur dimanfaatkan oleh Kufed, misalnya pada konten foto, karena foto yang diposting sudah diolah oleh tim kreatif dengan proses digital imaging (DI), maka fitur photo filter jarang sekali digunakan. Selain itu, fitur kamera juga tidak digunakan karena foto sudah diproduksi melalui kamera profesional. Maka dapat dikatakan dalam fitur Instagram oleh Kufed hanya dimanfaatkan sesuai dengan kebutuhannya saja. Fitur yang paling dimanfaatkan adalah Fitur pengikut, agar dapat berinteraksi dengan sesama pengguna, sehingga aktivitas yang dilakukan oleh Kufed dapat langsung terlihat pada timeline pengguna lain yang mengikutinya (follow). Hal ini sesuai dengan apa yang dikatakan oleh Atmoko (2012: 59), bahwa ciri khas jejaring sosial yang paling mencolok adalah kemampuannya untuk saling follow sesama pengguna, kemudian berkomentar dan memberikan tanda suka (like) pada foto. Dengan adanya fitur ini, maka interaksi yang akan didapatkan semakin besar peluangnya seperti memberikan komentar, memberi tanda suka pada posting tersebut, maupun mengirimkan pesan pribadi antar sesame akun yang telah saling follow.

Fitur lain yang dimanfaatkan oleh Kufed adalah tagar \# (hashtag), dengan tujuan untuk menandai foto dan mengelompokkannya ke dalam satu kategori tertentu (spesifik), berdasarkan kegemaran dari si pengguna. Fitur ini juga didukung oleh penggunaan Caption atau keterangan foto, yang berfungsi sebagai deskripsi dari sebuah postingan. Pengguna dapat menambahkan kata-kata yang menggambarkan foto yang diunggah dengan dapat pula menambahkan hashtag dalam caption tersebut. Pada umumnya caption lebih bersifat untuk memperkuat karakter atau pesan yang ingin disampaikan pada foto tersebut. Panjang karakter tulisan juga tidak ditentukan atau tidak ada aturannya (Atmoko, 2012: 52). Selanjutnya adalah fitur arroba (@), dimana fitur ini memungkinkan pengguna untuk saling menyapa (mention) pengguna lainnya yang dapat diterapkan dalam photo caption maupun comments. Kufed memanfaatkan fitur ini untuk mengaitkan sebuah postingan dengan pihak-pihak terkait, misalnya sebuah brand atau influencers yang telah bekerjasama dengan Kufed.

Fitur lain yang dimanfaatkan oleh Kufed yaitu pesan langsung (direct message), dimana fitur ini memungkinkan pengguna dapat mengirimkan pesan secara langsung kepada pengguna lainnya secara pribadi. Direct Message dimanfaatkan oleh Kufed untuk berkomunikasi langsung dengan followers, misalnya apabila followers menanyakan detail dan harga produk yang terpampang di dalam foto. Selain itu, direct message juga digunakan untuk berkenalan dengan calon influencers. Fitur selanjutnya adalah like, yang berfungsi untuk memberikan apresiasi apabila pengguna menyukai foto yang diunggah pengguna lain ke dalam akun Instagramnya. Kufed memanfaatkan fitur ini dengan tujuan untuk melihat apakah foto yang diposting menarik, hal ini dapat terlihat dari jumlah likes yang terdapat pada foto tersebut. Admin mengharapkan bahwa dengan fitur ini, Kufed dapat go viral dan memiliki engagement yang besar dengan followersnya. Fitur likes didukung oleh fitur comments, dimana para pengguna dapat saling berinteraksi secara terbuka, bukan hanya melalui kata-kata, tetapi juga lewat emoticon. Fitur-fitur yang dimanfaatkan oleh Kufed secara keseluruhan digunakan sebagai alat untuk 
menjalin interaksi dengan publiknya, yaitu para followers dan influencers secara ekspresif, dimana proses komunikasi untuk pengungkapan pesan bersifat reaktif dan terbuka, maka dapat dikatakan bahwa hal ini termasuk kedalam logika ekspresif.

2. Bagian Logika Konvensional

Dalam logika konvensional, komunikasi dianggap sebagai sebuah permainan yang dimainkan dengan peraturan. Logika ini bertujuan untuk menyusun pesan-pesan yang sopan, tepat, dan didasarkan pada aturan-aturan yang diketahui setiap orang (LittleJohn, 2009). Disini dapat terlihat bagaimana perencanaan strategi bekerja untuk menyajikan informasi atau pesan pada masyarakat sesuai pada aturan-aturan yang diketahui dan disetujui oleh komunikator maupun komunikan.

Salah satu ciri dari media sosial adalah fleksibel, hal ini memungkinkan terjadinya percakapan dari banyak orang ke banyak orang secara terbuka sehingga penyebaran informasi akan lebih mudah, cepat, dan menyeluruh tanpa terhambat ruang dan waktu. Media sosial bersifat digital, dimana pesan-pesan yang disampaikan dalam bentuk grafik, diagram, foto, teks, gambar gerak (video) yang diproses dan disimpan dalam bentuk angka dan menjadi output dalam bentuk online, disk digital, atau memori drive yang diterjemahkan dan diterima sebagai tampilan layar dan dikirim kembali melalui jaringan telekomunikasi (Lister, 2009).

Kufed sebagai komunikator menyajikan informasi melalui saluran media sosial dengan aturan-aturan yang telah diketahui dan telah melibatkan hak dan kewajiban dari targetnya. Pesan-pesan yang akan disampaikan direncanakan seefisien mungkin, memungkinkan agar followers dapat menyerap informasi dengan waktu yang singkat, cepat, dan efektif. Hal ini mendukung salah satu hak dari para followers yaitu dapat menjalin interativitas baik dengan Kufed maupun dengan sesama followers. Sehingga mereka dapat turut serta aktif dan berpartisipasi dalam kegiatan komunikasi yang terjalin. Sehingga, followers maupun influencers juga dapat menentukan konten apa saja yang bisa diterima dan konten apa saja yang tidak ingin diterima. Dengan kata lain, masyarakat pun yang memilih konten yang ingin mereka terima untuk dapat berinteraksi dengan pengguna lainnya.

Hal lain yang merupakan bagian dari logika konvensional adalah hypertextual, yaitu ciri khas media sosial yang melibatkan sebuah teks dimana teks tersebut dapat mengizinkan penggunanya untuk mengakses teks-teks lainnya (saling terhubung). Hal ini memudahkan Kufed dalam hal eksistensinya di dunia virtual. Seperti penautan sebuah teks (alamat) yang ditempel dalam kolom bio, maka akan terhubung ke official website yang dimiliki oleh Kufed. Seperti yang diungkapkan oleh Konsultan dari Kufed bahwa,

"[...] bisa nge-link ke yang lain juga. Kaya contoh, di Instagram kita, kita taro link di bio kita yang bisa langsung direct ke website kita, agar orang bisa dapetin informasi lebih banyak lagi sekaligus bisa langsung liat produk-produk yang kita juga, jadi mereka bisa langsung beli dan liat produk yang sudha kita post di Instagram tersebut. Jadi, pastinya orang lebih gampang untuk cari informasi tentang kita karena cuma dengan satu klik aja mereka bisa langsung ke website atau tautan lainnya."

Dengan begitu, pengguna akan mudah dalam mengambil informasi dari berbagai sumber karena tautan yang terhubung dari satu halaman ke halaman lainnya. Informasi yang disebarkan juga semakin banyak dan bervariasi.

Proses penyusunan pesan dibuat dengan tepat dan berdasarkan visi dan misi perusahaan secara user generated content, dimana pesan informasi yang disajikan adalah hasil dari keterlibatan publiknya 
juga, yaitu influencers, fashion fotografer, illustrator, beauty expert, stylist juga followers lainnya. Namun tentunya masih sesuai dengan selera dan gaya Kufed yang emotionless. Sehingga, pesan dalam bentuk konten dapat dinikmati bersamasama, baik dari komunikator maupun komunikannya. Dari aktivitas ini, Baik Kufed maupun pihak-pihak yang bekerjasama dapat memiliki karakter publik yang sama pula. Dapat dikatakan bahwa aktifitas ini merupakan kolaborasikonten untuk dinikmati publik secara keseluruhan dengan efek yang serempak.

Instagram dianggap oleh Kufed sebagai media yang paling tepat sebagai pendukung strategi komunikasinya. Kelebihan utamanya dalam bentuk visual dapat digunakan sebagai media penyampai teaser, yaitu penyampaian informasi yang hanya sepotong, agar para pengguna yang mengikutinya menjadi penasaran untuk mencari tahu informasi lebih lanjut. Informasi lengkapnya Kufed memberikan akses untuk tautan dimana pengunanya dapat langsung memperoleh detail informasi di website mereka maupun Facebook. Selain itu, inovasi yang dilakukan oleh Instagram baru-baru ini adalah fitur sponsor post, dimana pengguna dapat memasang konten informasi yang dapat di sebarkan kepada masyarakat luas di timeline dengan berbentuk iklan digital.

\section{Bagian Logika Retoris}

Dalam logika retoris, pesan-pesan yang disusun cenderung luwes, berwawasan, dan terpusat. Pada logika ini pula terlihat bagaimana pesan direncanakan dan diatur, guna strategi yang telah dibuat dapat menjadi satu kesatuan yang kuat sesuai dengan tujuan yang akan dicapai. Seperti yang dilakukan oleh Kufed, untuk mencapai tujuannya yaitu membuat kesadaran masyarakat akan kehadirannya sebagai salah satu pilihan berbelanja di dunia online, serta melakukan branding sebagai hasil kombinasi startup dari media sosial dan $e$ - commerce (social-commerce) yang berbasis aplikasi mobile dan website. Kufed menyediakan produk yang sudah di pilih (curated products) oleh para kurator dengan mempertimbangkan kualitas dan eksklusivitas dari produk tersebut.

Tidak hanya itu, Kufed menyediakan tempat bagi para penggunanya untuk membeli, menemukan barang favorit serta dapat membagi informasi dengan sesama pengguna lainnya yang berbentuk foto atau posting-an di akun pribadi pengguna mobile apps tersebut. Oleh karena itu, Kufed ingin memperkenalkan dirinya dan mengedukasi masyarakat tentang konsep tersebut. Pada pelaksanaannya, kegiatan ini dilakukan pada periode waktu yang berbeda-beda yang telah ditentukan, yaitu periode pre-launching, launching, dan post-launching. Pada periode prelaunching. Namun pada penelitian ini hanya terbatas pada tahapan pre-launching saja. Kufed menggunakan Instagram sebagai sebuah teaser berupa foto, gif, dan video dimana materi-materi tersebut akan dikemas oleh team marketing dan creative dari Kufed. Selain itu, Kufed tidak memakai strategi promosi seperti diskon, yang cendrung terkesan hard-selling atau cara yang digunakan untuk memasarkan produk yang dijual secara langsung (to the point), atau menyampaikan maksud seseorang untuk menjual produk kepada customer secara terang-terangan.

Pada tahapan pre-launching, melakukan riset perlu dilakukan guna mengetahui keadaan pasar dan karakter dari target yang akan dituju. Seperti yang dikatakan oleh Akademisi Media Sosial bahwa "mengetahui bagaimana karakter dari target yang ingin dituju sangatlah penting dalam pembuatan strategi agar sesuai dengan tujuan yang ingin dicapai”. Saat ini riset yang baru dilakukan oleh Kufed adalah dengan melakukan observasi lewat instagram, melihat peningkatan jumlah pengguna dan minat pengguna dalam menggunakan aplikasi mobile apps. 


\section{Penutup}

Berdasarkan hasil analisis dan pembahasan didapatkan simpulan bahwa Kufed memiliki strategi komunikasi antara lain; community building, di mana Kufed mendekatkan diri dan membangun hubungan dengan melibatkan targetnya kedalam aktivitas tertentu dan bekerjasama dalam pembuatan konten. Dalam segi konten, teks dan visual dibuat emotionless, dimana teks yang dirancang tidak memasukkan unsur emosional atau perasaan. Dengan tujuan penggunanya dapat memberikan respon tentang postingan tersebut (pengguna yang memberikan emosi kepada sebuah postingannya). Selanjutnya, pemilihan media Instagram juga merupakan salah satu strategi yang digunakan oleh Kufed, karena kelebihan Instagram yang bersifat visual, hal ini digunakan sebagai teaser berupa penggalan informasi kepada masyarakat seperti informasi mengenai produk yang dijual oleh Kufed. Ada pula beberapa fitur dari Instagram yang Kufed gunakan untuk menunjang konten mereka sesuai dengan kebutuhan konten tersebut seperti fitur pengikut, fitur tag dan hashtag, fitur caption, fitur arroba, fitur pesan langsung, fitur like, dan fitur komentar.

\section{Daftar Pustaka}

Atmoko, B.D. (2012). Instagram Handbook. Jakarta: PT. Trans Media.

Lister, M., et al. (2009). New Media: A Critical Introduction, Second Edition. New York: Routledge.
LittleJohn, S.W., and Foss, K.A. (2008). Teori Komunikasi (Theories of Human Communication) Edisi 9. Jakarta: Salemba Humanika.

Morissan. (2013). Teori Komunikasi Tentang Komunikator, Pesan, Percakapan, dan Hubungan (Interpersonal). Bogor: Ghalia Indonesia.

Severin, W. J. dan Tankard, J. W. (2011). Teori Komunikasi: Sejarah, Metode, dan Terapan di Dalam Media massa Edisi Ke 5. Jakarta: Kencana.

Somantri, G. R. (2005). Memahami Metode Kualitatif. Makara, Jurnal Sosial Humaniora, 9(02).

APJII (Asosiasi Penyelenggara Jasa Internet Indonesia). (2015). Profil Pengguna Internet Indonesia 2014. (E-Book) diperoleh dari http://www.apjii.or.id/v2/upload/stati stik/Survey\%20APJII\%202014\%20v 3.pdf

Hayden, B., dan Rafal, T. (2015, 10 Oktober, $\quad 10.00 \quad$ WIB), copyblogger.com. Retrieved from http://www.copyblogger.com/history -of-social-media/

Instagram @thekufed. Retrieved from https://www.instagram.com/thekufed

Internet World Stats 2016. Retrieved frohttp://www.internetworldstats.co $\mathrm{m} / \mathrm{stats} . \mathrm{htm}$.

Rachmatunnisa, (2016, 22 Juni, 12.56 WIB), detik.com. Retrieved from http://inet.detik.com/read/2016/06/22 /125655/3239352/398/pengguna instagram-tembus-500-juta 